\title{
TWO SIDES OF A COIN: PIERCING THE VEIL AND UNCONSCIONABILITY IN TRUST LAW*
}

\author{
Eben $\mathrm{Nel}$ \\ BJuris LLM LLD \\ Research Associate, Faculty of Law \\ Nelson Mandela Metropolitan University \\ Advocate of the High Court
}

\section{SUMMARY}

While the concept of unconscionability serves as a protection against unjust terms in a contract, a piercing of the corporate veil acts as protective measure against the misuse of the juristic personality. Both doctrines, therefore, empower the courts to police particular unjust behaviour in the corporate environment. The question is whether there is any real interworking between the two concepts, and if so, how such relationship should be applied by the courts in general, and more particularly in matters dealing with trusts. The article explores the interface between these two common-law doctrines as well as recent attempts by the legislature to codify some elements thereof. It is submitted that while both concepts rely on objective standards of fairness, justice and reasonableness, it is necessary for the judiciary to develop the interworking between the two concepts, with particular emphasis on a balance between the interests of individual participants in the business environment with that of commercial and contractual certainty. Particular emphasis is placed on public policy as a deserving evaluative benchmark for contractual relationships, which will include the principles of fairness, equity, justice, good faith and reasonableness.

\section{INTRODUCTION}

The trust figure has never been recognized in South African law as a juristic entity in the technical, legal sense, although it has sometimes been defined as a juristic person for particular purposes. ${ }^{1}$ In a narrow sense it is generally referred to as a "legal institution", but not as a legal person. ${ }^{2}$ Piercing of the corporate veil is a concept that developed in company law and is not often associated with a non-corporate legal figure such as the trust. In recent years it did, however, find its way into trusts, particularly where an individual

* This article is based partly on research done towards an LLD thesis titled "The Business Trust and its Role as an Entity in the Financial Environment" (2012 Nelson Mandela Metropolitan University) with Prof Vivienne Lawack as promoter and Professor Adriaan van der Walt as co-promoter.

See the definition of "juristic person" in section 1 of the Companies Act 71 of 2008.

2 See Cameron, De Waal and Wunsch Honoré's South African Law of Trusts (2002) 19. Compare Smith Authorisation of Trustees in the South African Law of Trusts (2006 LLM dissertation University of the Free State) 4-5. 
uses trust assets in a purely personal capacity. ${ }^{3}$ The piercing of the trust veneer has become a reality in South African trust law; and courts will treat the trust as if it has a separate legal personality, in order to reveal the "true villain of the piece". ${ }^{4}$

The concepts of unconscionability and piercing the veil deal - on the face of it - with two unrelated principles. While the first acts as a defence against terms in a contract that is so unjust, unfair or unreasonable to a given party to that contract, that no reasonable or informed person would agree to it, ${ }^{5}$ the corporate veil will, as general rule, be lifted when the corporate personality of a legal entity is being misused to cover fraudulent or other improper behaviour. The piercing of the veil principle is, therefore, a basis on which the culprits can be held personally liable for their wrongful actions perpetrated in the name of the legal entity, ${ }^{6}$ while the concept of unconscionability enables a court to decline to enforce a contract whose terms are seriously one-sided, overreaching, exploitative, or otherwise fundamentally unfair.

The purpose of both the above doctrines is thus to protect against unjust behaviour by a third party in a particular relationship - either purely contractually or as a result of acting as the representative of a juristic person $^{8}-$ by empowering the courts to police particular behaviour. ${ }^{9}$

The question is whether there is any real interworking between the doctrine of piercing the veil and the concept of unconscionability, and if so, how such relationship should be applied by the courts.

3 See National Union Fire Ins. Co. of Pittsburgh, Pa. $v$ Eagle Equipment Trust 221 A.D. $2 d$ 212, 212-213. Compare Vitiello and Kessler "Piercing the Veil: How Foolish Beneficiaries can Compromise Foolproof Trusts" 200811 New Jersey LJ 535.

4 Knoop NO v Birkenstock Properties (Pty) Ltd [2009] ZAFSHC 67 par 17; and compare Rees $v$ Harris 2012 (1) SA 583 (GSJ).

5 Chief Justice Fuller in Hume $v$ United States 132 U.S. 406, 411 (1889) held that an unconscionable contract is an agreement "such as no man in his senses and not under delusion would make on the one hand, and as no honest and fair man would accept on the other ..." Georgakopoulos "Contract-Centre Veil Piercing" April 2007 Indiana University School of Law (Selected Works) $10 \mathrm{http}: / /$ works.bepress.com/nicholas georgakopoulos/1 1 29, 10 argues very capably that without the concept of piercing the veil both the common and civil contract-law protections are inadequate to effectively protect contractual parties.

6 See Cilliers and Luiz "The Corporate Veil - an Unnecessarily Confining Corset?" 1996 THRHR 523-527.

7 Watt Trusts and Equity (2006) 76 submits that the term "unconscionability" "defines itself against a background of established laws of general application" and "describe(s) an oppressive abuse of legal rights and powers".

8 Although it is trite law that the South African trust is not generally regarded as a legal entity, for the purpose of this article any reference to legal entities will include a trust. It is sometimes regarded as a legal entity, but not as a juristic person. See Cameron et al Honoré's South African Law of Trusts 67-72; and compare also Commissioner for Inland Revenue v Friedman NO 1993 (1) SA 353 (A).

9 Stuntebeck "The Doctrine of Unconscionability" 1968 Maine LR 8191 submits that the real value of the doctrine of unconscionability lies in the policing aspect thereof, as skilled draftsmen of contracts often lose sight of the general principles of "fairness and decency". DiMatteo and Rich "A Consent Theory of Unconscionability: An Empirical Study of Law in Action" 200633 Florida State University LR 10661080 , refer to the difficulty of a fixed definition in a section called "Defining the Undefinable". 


\section{THE DOCTRINE OF PIERCING THE VEIL}

One of the first instances where the principle of piercing the corporate veil was applied in South African law was in Orkin Bros Ltd $v$ Bell, ${ }^{10}$ where the directors of a company were held personally liable to a seller who sold goods to a company at the instance of its directors. They knew the company to be insolvent and the sole purpose of the transaction was to diminish the personal liability of the directors under a contract of suretyship. This was held to constitute fraud on the seller, who obtained judgment against the directors personally. ${ }^{11}$ Le Roux J, in Lategan NNO $v$ Boyes ${ }^{12}$ held, "our Courts would brush aside the veil of corporate identity time and again where fraudulent use is made of the fiction of legal personality".

In Botha $v$ Van Niekerk, ${ }^{13}$ Flemming J, came to the conclusion, after a comprehensive analysis of the legal position, that personal liability would only become justifiable when it is clear that the third party suffered an unconscionable injustice because of the unjust actions of the liable party.

In Cape Pacific ${ }^{14}$ it was held that lifting the corporate veil means

"disregarding the dichotomy between a company and the natural person behind it (or in control of its activities) and attributing liability to that person where he has misused or abused the principle of corporate personality".

Smalberger JA, further submits in Cape Pacific that the preservation of the corporate identity must be balanced against policy considerations which arise in favour of piercing the corporate veil, and will, therefore, "look at substance rather than form in order to arrive at the true facts". ${ }^{15}$ These policy considerations may include fraud, dishonesty, improper conduct, an improper purpose, or where the company was used as a facade. Smalberger warns against a rigid test and supports a flexible approach which allows the facts of each case to determine "whether the piercing of the corporate veil is called for". ${ }^{16}$

In Hülse-Reutter v Gödde it was held by Scott JA, that "the separate legal personality of a company is to be recognised and upheld except in the most unusual circumstances". The court acknowledges that the exact circumstances in which it must be disregarded are far from settled, but will depend on an analysis of "the facts of each case, considerations of policy and judicial judgment". ${ }^{17}$

\footnotetext{
1921 TPD 92.

1 Le Roux J, refers to this case in Lategan NNO v Boyes 1980 (4) SA 191 (T) 201I. He is of the opinion that this principle was not applied in In re Yeridje Tobacco E Co Ltd (1916) $2 \mathrm{Ch}$ 426 and $R v$ Gillett 1929 AD 364, as the directors were held responsible in terms of statute and not because the veil was pierced.

121980 (4) SA 191 (T) $202 \mathrm{H}$.

131983 (3) SA 513 (W) 525E-F.

14 Cape Pacific Ltd v Lubner Controlling Investments (Pty) Ltd 1995 (4) SA 790 (A) $802 \mathrm{~F}-\mathrm{I}$.

15 803І-J.

$16805 \mathrm{~F}$

17 Hülse-Reutter v Gödde 2001 (4) SA 1336 (SCA) par 20.
} 
In the more recent matter of Airport Cold Storage (Pty) Ltd $v$ Ebrahim ${ }^{18}$ the court reiterated that directors and members must enjoy extensive protection against personal liability, but that such protection can never be absolute. In exceptional circumstances the corporate veil may, therefore, be pierced, lifted or drawn aside.

In Amlin (SA) Pty Ltd $v$ Van Kooij ${ }^{19}$ fraud, agency, evasion, abuse of the corporate form, and the creation of a mere facade to conceal the true state of affairs or as a means or device to conceal wrongdoing or to avoid obligations, were all submitted as justifiable motivations for piercing the veil. $^{20}$ Van der Linde and Lombard ${ }^{21}$ refer to equitable considerations to be taken into account when the necessity of piercing the corporate veil is considered.

To pierce the veil implies that the legal existence of the juristic person is ignored "for the purposes of adjudicating the rights and liabilities of the parties to the particular dispute". ${ }^{22}$ For all other purposes, the separate legal existence of the legal entity is still recognized.

Although the law is far from settled with regard to the exact circumstances in which it would be permissible to pierce the corporate veil, ${ }^{23}$ various tests have developed during the last three decades in South Africa for determining circumstances under which it is justifiable to pierce the veil of corporate identity. Each case will involve a process of inquiring into the specific facts, while bearing in mind "the fundamental doctrine that the law regards the substance rather than the form of things". ${ }^{24}$

182008 (2) SA 303 (C). Compare Die Dros (Pty) Ltd v Telefon Beverages CC 2003 (4) SA 207 (C), where the court held that fraud, dishonesty or other improper conduct may justify the piercing of the veil. See Haygro Catering BK v Van der Merwe 1996 (4) SA 1063 (C), where the court applied the doctrine after the members failed to display the name of the business on the premises as well as on the close corporation documentation.

192008 (2) SA 558568 in reference to Adams v Cape Industries plc [1990] Ch 433 ([1991] 1 All ER 929). See also Le'Bergo Fashions CC v Lee and Another 19982 SA 608 (C), where a restraint of trade was contravened to the advantage of a close corporation by the corporation's sole member. In The Shipping Corporation of India Ltd v Evdomon Corporation 19941 SA 550 (A) 566, the Appeal Court confirmed that some element of fraud or other improper conduct is normally necessary to move a court to allow a piercing of the veil.

20 Dlodlo $\mathrm{J}$ in Amlin (SA) Pty Ltd $v$ Van Kooijn supra 564-567 investigated the application of the piercing doctrine in a number of foreign jurisdictions and identified the following tests, namely: companies acting as puppets of another, acting fraudulently or using a company as a tool or conduit of another company (Canada); for equity means (USA); and as a mere façade (UK). He referred on 566 to City of Glasgow District Council v Hamlet Textiles Ltd Atlas Marine Co SA v Avalon Maritime Ltd [1991] 4 All SA ER (CA), wherein it was argued that the court, after taking into account all relevant circumstances, would pierce the veil only "where the interests of justice or fairness or right dealing so demand".

21 In "Identity of Interest between Trustees and Beneficiaries in so far as Object of Trust is Concerned" 2007 De Jure 429437 and their reference to the submissions of Benade "Verontagsaming van die Selfstandigheid van die Maatskappy-regspersoon" 1967 THRHR 213, and Davids "The lingering question: Some Perspectives on the Lifting of the Corporate Veil" 1994 TSAR 155 in favour of an equitable doctrine. Contra Botha $v$ Van Niekerk supra 523.

22 Davis, Cassim and Geach Companies and Other Business Structures in South Africa (2009) 21.

23 See Smalberger JA, in Cape Pacific Ltd $v$ Lubner Controlling Investments (Pty) Ltd supra $802 \mathrm{H}$.

24 Cape Pacific Ltd v Lubner Controlling Investments (Pty) Ltd supra 791A. 
The legislature recently created some direction by way of section 20(9) of the Companies Act 71 of 2008, as amended by the Companies Amendment Act 3 of 2011, both of which became effective on 1 May 2011. Section 20(9) codified the doctrine of piercing the corporate veil and reads as follows:

"If, on application by an interested person or in any proceedings in which a company is involved, a court finds that the incorporation of the company, any use of the company, or any act by or on behalf of the company constitutes an unconscionable abuse of the juristic personality of the company as a separate entity, the court may -

(a) declare that the company is to be deemed not to be a juristic person in respect of any right, obligation or liability of the company or of a shareholder of the company or, in the case of a non-profit company, a member of the company, or of another person specified in the declaration; and

(b) make any further order the court considers appropriate to give effect to a declaration contemplated in paragraph (a)."

The statutory remedy grants the courts the opportunity to discard the separate legal personality of the company on the basis that it was misused. ${ }^{25}$ Even shareholders may be held liable by any interested party. ${ }^{26}$ This may incentivise all stakeholders to uphold the integrity of the corporation and its actions in all proceedings and business transactions. It may, however, be difficult to determine when a company was used for abusing practices or when abusing practices were conducted on behalf of the corporation. ${ }^{27}$ Some suggest that this codification may give shareholders the incentive to make provision in the memorandum of incorporation to protect themselves against certain actions by the directors of the company.

Section 20(9) was recently referred to by Binns-Ward J, in the matter of Ex Parte Gore ${ }^{29}$ as affording a "firm, albeit very flexibly defined, basis for the remedy". The court also found -

(a) that the term "unconscionable abuse" detracts from the previously held notion that the doctrine can only be used as a drastic measure or when exceptional circumstances exist;

(b) that the requirement is diverse enough to cover the large variety of descriptions used in the past, such as "sham", "device", "stratagem" and many others;

25 Other instances where a company's separate legal personality may be ignored are in terms of S 165 (derivative actions), 161(1)(b) and 218(2) (civil actions). See Stein The New Companies Act Unlocked - A Businesspersons' Guide (2011) 374-375.

26 See s 218(2) of the Act.

27 See Schoeman "Piercing the Corporate Veil under the New Companies Act" 2012 June De Rebus 26 28, which submits that the legislature followed the same conservative approach that the courts have followed before, and that the term "unconscionable" highlights this approach.

28 See "Access to Justice: Human Rights Abuses Involving Corporations - South Africa", a project of the International Commission of Jurists, Geneva, Switzerland, 2010, 8-10 www.icj.org (accessed 12-02-2011), where it is proposed that the memorandum include a clause stipulating that one of the purposes of the company is to uphold the Bill of Rights entrenched in the Constitution. Because actions contrary to such a stipulation will be ultra vires, shareholders can act against directors who do not abide by it.

29 Ex Parte Gore NO [2013] 2 All SA 437 (WCC) par 34. 
(c) that the remedy can be used "whenever the illegitimate use of the concept of juristic personality adversely affects a third party in a way that should not reasonably be countenanced";

(d) that "it would be appropriate to regard section 20(9) of the Companies Act as supplemental to the common law, rather than substitutive";

(e) that the remedy may even be applicable when there are alternative remedies.

Although the courts would have to determine the exact contents of unconscionability as utilized in section 20(9), it is generally accepted that this doctrine requires both a procedural and a substantive element. ${ }^{30}$ It is submitted that "an unconscionable abuse" will require mala fides on the part of the company representative, resulting in substantive unfairness to the other contracting party. ${ }^{31}$ (The court in Ex Parte Gore found, incidentally, that "unconscionable abuse" is a lesser form of abuse than the "gross abuse" requirement in section 65 of the Close Corporations Act.) ${ }^{32}$

\section{PIERCING THE VEIL IN TRUST LAW}

Hyland and Smith ${ }^{33}$ submit that piercing of the veneer takes place when a trust is used as a "mere smokescreen ... to achieve other (ulterior) motives".

A piercing of the trust veil will take place when the ownership and the control of the assets of the trust vest in the same party to such an extent that the trust becomes the alter ego of that individual. Any attempt to differentiate between the two would be artificial, and has the potential to prejudice creditors and other third parties.

The application of the piercing-of-the-veil doctrine to trusts has not received the same amount of attention as its application to corporations. In the United States it was acknowledged that in the case of a so-called "dummy" trust, where an individual uses the trust assets in a purely personal capacity, the use of the piercing theory would be justified. ${ }^{34}$ It was submitted that in a trust context the piercing doctrine becomes justifiable when someone exercised such control over the trust that it became a "mere

30 Horton "Unconscionability in the Law of Trusts" 2008 Law Review, Berkeley School of Law, University of California 1-57 http://ssrn.com/abstract=1280363 (accessed 2011-08-06).

31 See Glover The Doctrine of Duress in the Law of Contract and Unjustified Enrichment in South Africa (2003 DPhil thesis Rhodes University) 373-443. Berat "South African Contract Law: The Need for a Concept of Unconscionability" in May and Brown (eds) Philosophy of Law (2009) 501-510, argue in support of the integration of the doctrine in the SA jurisdiction as a matter of fairness to a less educated population. See also Berat "South African Contract Law: The Need for a Concept of Unconscionability" 199214 Angeles International and Comparative LJ 507-527. For application of the doctrine, see Marrow "Squeezing Subjectivity from the Doctrine of Unconscionability" 200553 Cleveland State LR 187-224.

32 Ex Parte Gore NO supra [34].

33 Hyland and Smith "Abuse of the Trust Figure in South Africa: An Analysis of a Number of Recent Developments" 20061 Journal for Estate Planning Law 1. See their discussion on 11-14 on Jordaan v Jordaan 2001 (3) SA 288 (C); and Badenhorst v Badenhorst 2006 (2) SA 255 (SCA).

34 National Union Fire Ins. Co. of Pittsburgh, Pa. v Eagle Equipment Trust supra 212-213. 
instrumentality or alter ego of that individual", and when the person used that control to commit a wrongful action that caused injury to a third party. ${ }^{35}$

In Creighton Trust $v \mathrm{ClR}^{36}$ it was held that the donor remained in full control of the trust property and had, for his own benefit, "the control, order or disposition of the property". The court, therefore, looked past the trust and determined that the trust property had to be deemed property, passing on the death of the donor.

In Jordaan $v$ Jordaan, Traverso $\mathrm{J}$ found, on the respondent's own evidence, that the trust became his alter ego and was indeed viewed as such by the respondent himself. The court looked through the trust entity and ruled that the trust assets had to be taken into account for the redistribution order. ${ }^{37}$

In Badenhorst the appellant alleged that the trust was in effect the alter ego of the respondent. Although Combrinck AJA, did not make a direct finding in this regard, he did find that the respondent was in "full control of the trust" and that he had "paid scant regard to the difference between trust assets and his own assets". ${ }^{38}$ It is made clear that control over the assets of the trust must be a de facto control, irrespective of the de iure position. ${ }^{39}$

In Knoop NO v Birkenstock Properties (Pty) $L t d,{ }^{40}$ the applicants alleged that the insolvent was using a trust as a front for her own benefit even though her estate had been sequestrated. They had to prove that the insolvent had misused or abused the principle of corporate personality and that the trust property was in fact the property of the respondent. Where a corporate entity was properly established but has been misused to perpetrate fraud, or to serve a dishonest or improper purpose, the separate personality may be disregarded in the relation to the specific transaction, while giving full effect to it in other respects.

Nxusani AJ, held in Knoop that "it matters not whether the corporate entity is a trust or a company. Provided that it can be established on a balance of probabilities that the particular transactions complained of were the tainted fruits of fraud or other improper conduct, a court would, in appropriate circumstances, disregard the separate legal personality in order to reveal the perpetrator as the "true villain of the piece".

In the very recent matter of Rees $v$ Harris, ${ }^{43}$ the court tested for piercing of the trust veneer and decided that there were no facts placed before it in court which could justify the inference that the assets of the trust belonged to

35 Vitiello and Kessler 200811 New Jersey Law Journal 535; and see also In re Maghazeh, 310 B.R.5 (Bkrptcy), E.D. N.Y. 2004.

$36 \quad 1955$ (3) SA 498 (T) 502E.

37 Jordaan $v$ Jordaan supra 301B-C.

38 Badenhorst $v$ Badenhorst supra $261 \mathrm{H}$.

39 Badenhorst $v$ Badenhorst supra 261A. Also applied in Brunette $v$ Brunette 20095 SA 81 (SECLD) 83D-G. In Nel v Metequity Ltd 2007 (3) SA 34 (SCA) par 5 it was stated by Cameron JA that "the core idea of the trust is the separation of ownership (or control) from enjoyment".

40 Supra.

41 Supra par 16.

42 Supra par 17

43 Supra. 
the trustee in his personal capacity, or that he had been in de facto control of the trust to the exclusion of his co-trustee. Nor were adequate facts put forward to indicate that the trustee treated the trust as his alter ego.

It is submitted that the piercing-of-the-veil principle has been successfully extended to South African trust law and that it is justifiable to apply the doctrine of piercing of the trust veil or veneer on the same basis as the piercing of the corporate veil. ${ }^{44}$ It is submitted, however, that the manner in which the application of the common law principle developed in South African trust law during the last decade is satisfactory and the courts do not have to rely on the statutory requirement of unconscionable abuse created in the Companies Act. Neither is it necessary for the legislature to intervene.

\section{THE CONCEPT OF "UNCONSCIONABILITY"}

The expression "the principle of unconscionability" is a reference to a term or terms in a contract that is/are so unjust, unfair and/or unreasonable to a given party to that contract that no reasonable or informed person would agree to it. Fuller CJ, held that it is an agreement "... such as no man in his senses and not under delusion would make on the one hand, and as no honest and fair man would accept on the other ..., ${ }^{45}$ Although a number of factors, such as duress, undue influence, deceit, mistake, fraud, violence, coercion, misrepresentation and forfeiture, may indicate the presence of an unconscionable term in a particular contract, it is not always that obvious to identify. ${ }^{46}$

The underlying motivation for the doctrine of unconscionability is the due process of law - which in practical terms is a purposeful protection of the weak against the strong. ${ }^{47}$ Although thus based on an objective test of fairness, the doctrine does have the potential of negating the very essence of contractual freedom - which is at the heart of a developed commercial environment. As all contracts are negotiated within a particular set of socioeconomic realities, the test for unconscionability should be applied objectively, but with due consideration to the parties, facts, place and time. ${ }^{48}$

44 In First Rand Limited v Britz [2011] ZAGPPHC 119; 54742/09 (20-07-2011) (unreported) Mabuse J, applied the principles of the corporate "piercing-the-veil" doctrine directly to trusts. He even applied s 65 of the Close Corporation Act 69 of 1984 to the trust. Although there are many aspects of the judgment that can be criticized, and even the end result can be seriously challenged, the judgment does give an indication of how our courts may in future bring the trust and the corporation closer to each other. Compare Stafford $A$ LegalComparative Study of the Interpretation and Application of the Doctrines of the Sham and the Alter-ego in the Context of South African Trust Law: The Dangers of Translocating Company Law Principles into Trust Law (2010 LLM dissertation Rhodes University) 125-133 for a somewhat different approach to this issue.

45 See Hume $v$ United States supra.

46 See s 2-302 of the Uniform Commercial Code. The Code was originally enacted in 1952 and amended many times since. The Code is not itself the law, but only a recommendation of the laws that should be adopted in the different states. They may either adopt the Code as is or may adopt it with particular changes.

47 Dolinger "UnconscionabilityAround the World: Seven Perspectives on the Contractual Doctrine" July 1992 14(3) Loyola of Los Angeles International and Comparative LJ 435437. See also Barnard "A Critical Legal Argument for Contractual Justice in the South African Law of Contract" (2005 LLD thesis University of Pretoria) 235-246 for an evaluation of the human-rights element in contract law.

48 Dolinger July 1992 14(3) Loyola of Los Angeles International and Comparative LJ 436. 
A healthy balance must be struck between the importance of protecting the legal and commercial value placed on contractual certainty versus the creation of an over-protective environment of which valuable potential players steer clear. ${ }^{49}$ It can be argued that the doctrine of unconscionability must not be regarded as an inhibitor of contractual freedom, but rather as an inhibitor of contractual abuse. ${ }^{50}$

Unequal parties contracting with each other are often also not equally free, as a significantly unequal relationship between the parties, leaving one of them with no meaningful level of bargaining power, resulting in terms that are unreasonably favourable to the stronger party, should not necessarily be protected to the same level. ${ }^{51}$ At the same time, a commercial environment where contracting parties do not honour their commitments, may have a negative impact on the marketplace, with an even greater impact on the weaker players. ${ }^{52}$

In evaluating the reasonableness of a contract, a number of factors may influence the outcome, such as the particular commercial setting, the purpose of the contract, and the ultimate effect thereof, while the commercial setting of the contract may be influenced by a variety of aspects, such as the history of the agreement, the factors leading to the agreement, the business risks involved, and the distribution of such risks among the parties to the agreement. $^{53}$

For the doctrine of unconscionability in contract law to fulfil its role effectively, without prejudicing the commercial integrity of the particular jurisdiction, certainty of law, combined with a trustworthy and consistent judiciary, is a prerequisite. The stronger party must believe that an agreement will be honoured, and if not, he/she will be adequately protected, while the weaker party must believe that he/she will not be unconscionably prejudiced. In this process, it is imperative that the development of the doctrine of unconscionability create clear guidelines of fairness and deter vague premises of decision-making. ${ }^{54}$

While jealously guarding contractual integrity and preventing the commercial arena from falling into disarray, the presumption that people usually contract in their own best interest, must not be followed blindly, as subjective factors such as fear or greed may taint good judgment. In some

49 Compare "Investigation into Unreasonable Stipulations in Contracts and the Rectification of Contracts" (Project 47) Discussion Paper 65, 7 August 1996, Media Statement by the South African Law Commission. Compare the role of the Consumer Protection Act 68 of 2009 in this regard.

50 See the criticism by Lewis "The Uneven Journey to Uncertainty in Contract" 2013 76(1) THRHR 80-89 on some obiter remarks by the court in Everfresh Market Virginia (Pty) Ltd v Shoprite Checkers (Pty) Ltd 2012 (1) SA 256. She submits that, as the majority did not reject the suggestion that there may have been a duty on the parties to the contract to negotiate in good faith, the notion of legality was actually undermined.

51 See Williams $v$ Walker-Thomas Furniture Co. 350 F.2d 445, 449 (1965). In Murphy $v$ McNamara, 38 Conn Super 183, 416 A 2d 170 (1979) it was found that unequal bargaining power resulting in an unconscionable purchase price, is unfair.

52 In Rowe $v$ Great Atlantic \& Pacific Tea Company 385 N.E.2d 566 (N.Y. 1978) 569, the court referred to the tension between freedom of contract and the need for protection against "the potentially harsh effects of an unchecked free-market system".

53 See In Re Elkins-Dell Manufacturing Co. 235.F.Supp 864, 873 (E.D.Pa 1966).

54 See Stuntebeck 1968 Maine LR 91. 
jurisdictions, an evaluative system, distinguishing between procedural and substantive aspects of unconscionability, has been developed, which resulted in a rather complex process in some matters. ${ }^{55}$ Procedurally unconscionable stipulations included aspects such as hidden or nonconspicuous clauses, the use of language that is incomprehensible to the layperson, inequality of bargaining powers, exploitation of the uneducated, and factors such as age, education, intelligence, business acumen and experience, while substantively unconscionable factors include excessive pricing, significant cost-price disparity, denial of basic rights and remedies, the inclusion of penalty clauses, the limitation of liability and an overall imbalance in the transaction. ${ }^{56}$

\section{UNCONSCIONABILITY IN TRUST LAW}

The term "unconscionable" was first introduced to South African law in 1983 when it was decided in Botha $v$ Van Niekerk ${ }^{57}$ that personal liability only becomes justifiable when it is clear that the third party has suffered an "unconscionable injustice" because of the unjust actions of the liable party. ${ }^{58}$

In 1998, the South African Law Commission had to determine whether courts should be able to give relief to unfortunate contractual parties, ${ }^{59}$ and recommended that a court should indeed be able to interfere in a contract when it is of the opinion that the way the contract came into being, or the form, execution or enforcement thereof, "is unreasonable, unconscionable or oppressive".$^{0}$ The specific guidelines given for determining such procedural or substantive unfairness, included the bargaining power of the respective parties, standards of fairness, the extent of negotiation, and the context of the contract as a whole. ${ }^{61}$ Proposed preventative mechanisms included peremptory cooling-off periods, the exemption of voetstoots clauses, as well as a general prohibition against standard-form contracts. ${ }^{62}$ Because there was no "general theory of unconscionability allowing a court to interfere with

55 Since Williams $v$ Walker-Thomas Furniture Company supra, the courts have evaluated two aspects: unfairness in formation of the contract, and excessively disproportionate terms. See Sitogum Holdings Incorporated 800 A.2d at 921 in this regard.

56 DiMatteo and Rich 200633 Florida State University LR 1076-1080.

57 Supra.

58 See Botha $v$ Van Niekerk supra 525E-F. See Che and Spier "Strategic Judgment Proofing" 2008 Harvard Law and Economic Discussion Paper no 618 http://papers.ssm.com/ sol3/papers.cfm?abstract_id=1159184 (accessed 2011-08-06).

59 South African Law Commission Report: Project 47 "Unreasonable Stipulations in Contracts and the Rectification of Contracts" April 1998 par 1.3. The object of the project, according to par 1.1, was "to consider whether courts should be enabled to remedy contracts or contractual terms that are unjust or unconscionable ..."

60 South African Law Commission Final Report on Project 47: "Unreasonable Stipulations in Contracts and the Rectification of Contracts" (1998) 213-218. See Glover The Doctrine of Duress in the Law of Contract and Unjustified Enrichment in South Africa 373-376, submitting that "the terms 'unconscionability' and 'good faith' would probably seem like two sides of the same coin".

61 See Horton 2008 Law Review, Berkeley School of Law, University of California 1-57 http://ssrn.com/abstract=1280363 (accessed 2011-08-06), for a discussion on the differences between procedural and substantive conscionability.

62 SA Law Commission Report par 1.11 and 1.12. 
a contractual relationship merely on the ground of unfairness", ${ }^{63}$ it became apparent that particular interventions were needed.

Although the recommendations of the Commission were not legislatively implemented, the courts did manage to find ways to deal with matters of gross unfairness in contractual law. In Potgieter v Potgieter ${ }^{64}$ Brand JA held, with reference to Barkhuizen $v$ Napier ${ }^{65}$ that "as a matter of public policy, our courts can refuse to give effect to ... contractual provisions which it regards as unreasonable and unfair". It was submitted by the court that "(r)easonableness and fairness are not freestanding requirements for the exercising of a contractual right." ${ }^{66}$ Values such as good faith, reasonableness and fairness are thus not to be regarded as "independent substantive rules" of contract, ${ }^{67}$ and courts may not subjectively decide that a particular contractual term is contravening such a value or values. ${ }^{68}$

The concept of unconscionability was legislatively introduced to South African law only when the term "unconscionable" was defined in the Consumer Protection Act of $2009,{ }^{69}$ describing it as "unethical or improper to a degree that would shock the conscience of a reasonable person". Section 40 explains "unconscionable behaviour", in the specific context, as the use of physical force, coercion, undue influence, pressure, duress, harassment, unfair tactics, or similar conduct. It further describes as "unconscionable" the taking of advantage of a consumer who is "substantially unable" to protect himself, because of physical or mental disability, illiteracy, ignorance, inability to understand the language of an agreement, or a similar factor.

The term "unconscionability" was further legislatively included in subsection 20(9) of the Companies Act of 2008, ${ }^{70}$ which provides that, if "a court finds that the incorporation of the company, any use of the company, or any act by or on behalf of the company, constitutes an unconscionable abuse of the juristic personality of the company as a separate entity", the court may declare the corporate veil to have been pierced in respect of any right, obligation or liability of the company or of a shareholder of the company.

\section{THE INTERFACE: PIERCING THE VEIL AND UNCONSCIONABILITY IN TRUST LAW}

As indicated above, section 20(9) of the Companies Act codified the doctrine of piercing the corporate veil and the statutory remedy in subsection 20(9)(a) which grant the courts the opportunity to discard the separate legal

63 Report par 1.34.

64 Potgieter v Potgieter NO 2012 (1) SA 637 (SCA) par 32; [2011] ZASCA 181; 629/2010 (3009-2011).

652007 (5) SA 323 (CC). Ngcobo J, explains in Barkhuizen $v$ Napier supra par [80] that the notion of "good faith" includes concepts such as justice, reasonableness and fairness.

66 Potgieter v Potgieter supra par 32. Brand JA, refers to Bredenkamp v Standard Bank of SA Ltd 2010 (4) SA 468 (SCA) par 53.

67 Potgieter v Potgieter supra par 32.

68 Compare Barkhuizen v Napier supra par 82 where the court states that a doctrine such as "good faith" is not "a self-standing rule", but merely an underlying contractual value.

69 Act 68 of 2009

70 Act 71 of 2008 . 
personality of the company on the basis that it was misused. ${ }^{71}$ In this section the concepts of unconscionability and the piercing of the corporate veil have been connected by setting unconscionability as the standard for determining when the remedy of piercing the corporate veil is available.

The main requirement for the application of veil-piercing is that control of the trust assets vest in a trustee or other third party to such an extent that the trust as figure has become the alter ego of that person. When it becomes hard to differentiate effectively between the trust and the third party, creditors and other contractual parties may be prejudiced, as the trust and the third party can each hide behind the other. The application of the doctrine may be regarded as somewhat complex in a trust context, because of the lack of legal personality on the part of the trust. As so-called "trust assets" really vest in the trustees and not in the trust figure itself, the veil is even more figurative than in case of a juristic person. Someone in whom trust assets vest as in his/her capacity as trustee, may contravene that position by acting as if the assets actually vest in his/her personal estate. When the veneer of the trust form is disregarded, the contravening trustee may either be held personally liable to perform, or the trust may be held to the obligation incurred by the trustee(s) on its behalf. ${ }^{72}$

The applicability of the doctrine of unconscionability in trust law lies in the potential protection of the rights of beneficiaries. For this reason, the courts should be able to scrutinize procedurally suspicious clauses in trust deeds. ${ }^{73}$ Horton submits that a founder's right to dictate how the trust assets must be used in future has the potential to "cause negative externalities" ${ }^{\prime 4}$ and that the unconscionability rule, with its two-pronged procedural and substantive test, is able to detect certain prejudicial clauses that are not covered effectively by other protective rules in trust law. The procedural element is ideal to identify terms that are not consonant with what an informed founder would have chosen, while the substantial aspect focuses on potentially grossly unfair results that may be caused by a particular clause. ${ }^{75}$

Many trust deeds in South Africa are drafted in the form of one-size-fits-all shelf documents, some of which have not even been created by the parties themselves, but are taken over by way of a cession. The fact that the founder and trustees sign the trust deed does not necessarily prove that they

71 Other instances where a company's separate legal personality may be ignored are in terms of $s 165$ (derivative actions), 161(1)(b) and 218(2) of the Companies Act 2008. See Stein The New Companies Act Unlocked - A Businesspersons' Guide 374-375.

72 See Van der Merwe NO v Hydraberg Hydraulics CC; Van der Merwe NO v Bosman 2010 (5) SA 555 (WCC) [41].

73 See Horton 2008 Law Review, Berkeley School of Law, University of California 1-57 http://ssrn.com/abstract=1280363 (accessed 2011-08-06).

74 Horton 2008 Law Review, Berkeley School of Law, University of California 27 http://ssrn.com/abstract=1280363 (accessed 2011-08-06). He acknowledges the role of certain rules in US law to counteract such "negative externalities", like the "rule against perpetuities" and the "rules of property regimes or elective share statutes", protecting spouses from complete disinheritance. He gives a list of potentially hazardous testamentary-trust stipulations.

75 Horton 2008 Law Review, Berkeley School of Law, University of California 32 and 43 http://ssrn.com/abstract=1280363 (accessed 2011-08-06). In evaluating the causes of these undesirable clauses, Horton refers to so-called "mill trusts", "self-help trusts" and the role of corporate trustees in the process of creating trust deeds that do not necessarily stipulate what the settler had in mind. 
have consensus on its contents. ${ }^{76}$ It is submitted that it would be advantageous to incorporate a test like the conscionability test into trust law to broaden the power of courts to interfere with the contents of both mortis causa and inter vivos trusts on procedural and substantial grounds of unfairness.

Louw ${ }^{77}$ extends the unconscionability principle to the need for clear and simple language in documents. As a trust deed is often in the form of a contract, the parties have to be aware of all their obligations and rights in terms thereof. An unconscionable agreement may be grounds for cancellation. Alternatively, a court may redraft contractual terms that infringe on certain consumer rights. ${ }^{78}$ In terms of the Trust Property Control Act, a court may, where a trust instrument contains (a) provision(s) leading to unforeseen consequences which hamper the objectives of the founder, or prejudice the interests of beneficiaries, or is in conflict with the public interest, delete or vary such (a) provision(s), or issues another appropriate order in respect thereof. ${ }^{79}$ It is submitted that the principle of unconscionability goes further than this provision, as it includes aspects such as reasonableness and fairness, both procedurally and substantively.

The test of unconscionability has become a reality in the South African business milieu and trusts cannot be excluded from it. Trusts are often used as business vehicles and do qualify as juristic persons in terms of both the Consumer Protection Act and the Companies Act, and should grant the same protection to all affected parties as any other business form.

While piercing of the trust veneer is aimed at protection of contracting third parties, the test for unconscionability is usually applied with the interests of the beneficiary(-ies) of the trust at heart. Piercing is evaluated in light of the actions of the individuals involved in a contractual relationship, while unconscionability, on the other hand, is tested by evaluating the contract itself, creating certain rights, powers and obligations. In the case of piercing of the veil, the subjective behaviour of an individual is tested objectively, that is, it is a matter of substance more than of form, with a twopronged, albeit objective, procedural and substantive test aimed at determining whether there is/are (an) unconscionable provision(s) in the trust deed.

\section{CONCLUSION}

It is submitted that there is indeed an interworking between the doctrine of piercing the trust veil and the concept of unconscionability in trust deeds. Both rely heavily on objective standards of fairness, justice and reasonableness. The piercing doctrine is applied when aspects of fraud, dishonesty, improper conduct, abuse of form, improper purpose, equitable considerations and particular public-policy factors are present, while signs of duress, undue influence, oppression, deceit, mistake, fraud, violence,

76 For an example of this type of behaviour see Potgieter $v$ Potgieter NO [2011] ZASCA 181 (SCA) case no 629/2010.

77 See Louw "Simply Legal: Legal Language in South Africa" December 2011 De Rebus 2224.

$78 \mathrm{Ibid}$. Compare s 51, 52, 76 of the Consumer Protection Act 68 of 2008.

79 See s 13. 
coercion, misrepresentation and forfeiture may indicate the presence of (an) unconscionable term(s) in a trust deed. It is submitted that in both instances the overall purpose of the intervening principle is to prevent an unconscionable injustice from taking place. In section 20(9) of the Company Act the two concepts have been fused by the setting of unconscionability as the determining factor of abuse necessary to justify the piercing of the veil.

The term "unconscionable" can be defined as "not restrained by conscience", or "unscrupulous". It is submitted that Botha $v$ Van Niekerk, where objectively measured improper conduct resulting in unconscionable injustice was required, is authority for the acceptance of unconscionable behaviour by one or more of the parties to a trust deed as a ground for piercing the trust veil.

It is, therefore, suggested that the courts should take note of the interface between the two concepts, which may support the further development of both. An ad hoc approach to contractual unconscionability is currently followed in legislation, often with a consumer-protection agenda. It remains, however, imperative that the interests of individual fairness and justice are properly balanced with that of legal and contractual certainty.

Although the general principles of public policy to apply in contractual relationships are embedded in the values of the Constitution, and particularly in the Bill of Rights, neither contractors nor the courts can afford to lose sight of the importance of the inherent integrity of the agreement as business and social regulator. The application of objective standards of fairness, justice and reasonableness when contractual relationships are evaluated, should be exercised with the utmost care.

Brand is correct when he argues in favour of the application of a constitutionally-aligned public-policy doctrine in contract law - although this concept still needs "development and fine-tuning". ${ }^{82}$ It is submitted that the concept of public policy includes the elements of fairness, equity, justice, good faith and reasonableness. None of these can individually fulfil the role, but in combination they do lay a firm foundation for the establishment of a constitutionally-accountable evaluative mechanism to apply to the law of contract. $^{83}$

80 Supra 525E-F

81 See in this regard Barnard A Critical Legal Argument for Contractual Justice in the South African Law of Contract (2005 LLD thesis University of Pretoria) 203.

82 Brand "The Role of Good Faith, Equity and Fairness in the South African Law of Contract: The Influence of the Common Law and the Constitution" 2009 126(1) SALJ 71 87-89. See support for the application of the public-policy doctrine in Brisley $v$ Drotsky 2002 (4) SA 1 (SCA), Afrox v Healthcare Bpk v Strydom 2002 (6) SA 21 (SCA) and Napier v Barkhuizen [2006] 2 All SA 469 (SCA), endorsed in Barkhuizen v Napier supra.

83 See Bennett "An African Doctrine of Equity in South African Public Law" 201257 Loyola LR 709-726 for an evaluation of ubuntu as a value similar to that of equity and its potential public- and private-law application. 